\title{
Characteristics of an employment relationship as a legal relationship: "actually" legal relation of the obligation? Few remarks in the perspective of the social doctrine of Church
}

\section{Charakterystyka stosunku pracy jako stosunku prawnego: "rzeczywiście" prawny stosunek zobowiązania? Kilka uwag w kontekście społecznej doktryny Kościoła}

\author{
professor AMU Anna Musiała \\ Adam Mickiewicz University in Poznan, Faculty of Law and Administration \\ ORCID: 0000-0001-5788-9144 \\ e-mail: musiala@amu.edu.pl
}

\begin{abstract}
Summary The author is trying to answer the question whether the contemporary legislative view of the employment relationship as a legal relationship offers any chances of tracing the social doctrine of the Church there. Even though the legislation in force no longer claims that an employee performs work for the benefit of a "work establishment", this work establishment nevertheless continues to be present in the code legislation. Yet, is it really the case that work is surely not performed for the benefit of it? By answering "yes" to this question, the underlying assumption being that work establishment is understood as a community of people, you could talk of a certain doctrinal agreement between the normative view of the definition of employment relationship and the social teaching of the Church.
\end{abstract}

Keywords: employment relationship, social doctrine of the Church.

Streszczenie Autorka podejmuje próbę odpowiedzi na pytanie: czy dzisiejsze legislacyjne ujęcie stosunku pracy jako stosunku prawnego w ogóle daje szansę na poszukiwanie w nim jakichkolwiek śladów społecznej doktryny Kościoła? Choć w obowiązującym w Polsce prawie nie twierdzi się już, że to na rzecz ,zakładu pracy” pracownik świadczy pracę, to jednak zakład pracy ciągle funkcjonuje w ustawodawstwie kodeksowym. Ale czy pracy na jego rzecz już na pewno się nie świadczy? Zdaniem autorki odpowiadając na powyższe pytanie twierdząco — przy założeniu, że zakład pracy pojmuje się jako wspólnotę ludzi — można by mówić o pewnej doktrynalnej zgodności normatywnego ujęcia definicji stosunku pracy ze społeczną nauką Kościoła.

Słowa kluczowe: stosunek pracy, społeczna doktryna Kościoła.

JEL: K31

Str. 15-19 


\section{Bibliography}

Baran, K.W. Ćwiertniak, B. Mitrus, L. Sobczyk, A. (2005). Prawo pracy. Zakamycze.

Florek, L. (2017). Prawo pracy. Warszawa.

Kubot, Z. (1978). Pozycja prawna stron w umownym stosunku pracy. Wrocław.

Liszcz, T. (2004). Prawo pracy. Warszawa.

Longchamps de Bérier, F. (1964). O pojęciu stosunku prawnego w prawie administracyjnym. Acta Universitatis Wratislaviensis, issue 19, Prawo XII. Wrocław.

Musiała, A. (2019). Polskie prawo pracy a spoleczna nauka Kościoła. Poznań.

Proposition de code du Travail. Sous l'égide du Groupe de recherche pour un autre Code du travail. (GR-PACT). (2017). Dalloz.

Radwański, Z. Olejniczak, A. (2013). Prawo cywilne. Zobowiązania. Część ogólna. Warszawa.

Sobczyk, A. (2015). Wolność pracy i władza. Warszawa.

Stelina, J. (2017). In: A. Sobczyk (ed.), Kodeks pracy. Komentarz. Warszawa.

Ziembiński, Z. (1978). Teoria prawa. Warszawa.

Ziembiński, Z. (1980). Wstęp do prawoznawstwa. Warszawa. 